\title{
Dairy activity in family farming in Minas Gerais, Brazil: production costs and cost-effectiveness analysis
}

\author{
Atividade leiteira na agricultura familiar em Minas Gerais: custos \\ de produção e análise de rentabilidade
}

\author{
César Correia Santos ${ }^{1}$; Gercílio Alves de Almeida Júnior²; Marcos Aurélio Lopes ${ }^{3 *}$
}

\begin{abstract}
The aim of this study is to analyze and compare the cost-effectiveness of three family dairy farms, located in the municipality of Limeira do Oeste, MG, Brazil, as well as to identify the break-even points and the factors that most influenced the final costs, and their impacts on each property. The analyzed data comprised the period from May 2015 to May 2016 and were collected using forms developed by EMATER-MG (Technical Assistance and Rural Extension Company of the State of Minas Gerais) and MDA (Ministry of Agrarian Development). Gross and net margins as well as results (profit or loss) were considered as cost-effectiveness indices. It was realized that the dairy activity in the properties studied exhibited low efficiency in the use of inputs, implying idle productive capacity, an increase in the proportion of fixed costs in the composition of total costs, and low productivity per animal per unit area. Therefore, diary activity was highly dependent on the sale of animals in order to afford and present positive results. Among the components of the effective operating cost, feeding is the most representative (averaging 63.09\%), in the three studied properties, being the tax rates considered as fixed $(9.41 \%)$ and miscellaneous expenses $(9.49 \%)$ also expressive. The properties showed high fixed costs and break-even points; in one property, these could not be determined as the unit variable cost was higher than the average selling price in the market. In the economic analysis, the three systems showed positive net margins and results, indicative of production viability in the long term.
\end{abstract}

Key words: Dairy cattle. Effective operating cost. Break-even point.

\section{Resumo}

Objetivou-se analisar e comparar as rentabilidades de três propriedades familiares produtoras de leite, situadas no município de Limeira do Oeste-MG, bem como identificar o ponto de equilíbrio e os fatores que exerceram maiores representatividades nos custos finais e os impactos ocasionados por eles em cada propriedade. Os dados analisados compreenderam o período entre maio de 2015 a maio 2016 e foram coletados utilizando-se formulários desenvolvidos pela EMATER-MG (Empresa de Assistência Técnica e Extensão Rural do Estado de Minas Gerais) e MDA (Ministério do Desenvolvimento Agrário). Considerou-se as margens bruta e líquida, bem como o resultado (lucro ou prejuízo) como indicadores de rentabilidade. Percebeu-se que a atividade leiteira, nas propriedades estudadas, apresentou baixa eficiência de utilização dos fatores de produção o que implicou capacidade produtiva ociosa, elevação da

1 Extensionista, Empresa de Assistência Técnica e Extensão Rural do Estado de Minas Gerais, EMATER, Especialista em Extensão Ambiental para o Desenvolvimento Sustentável, Limeira do Oeste, MG, Brasil. E-mail: cesar.correia@emater.mg.gov.br

2 Prof. Associado, Universidade Federal do Espírito Santo, UFES, Departamento de Zootecnia, Alegre, ES, Brasil. E-mail: gercilio. almeida@ufes.br

3 Prof. Titular, Universidade Federal de Lavras, UFLA, Departamento de Medicina Veterinária, Bolsista do CNPq, Lavras, MG, Brasil. E-mail: malopes@dmv.ufla.br

* Author for correspondence

Received: May 18, 2017 - Approved: Jan. 24, 2018

Semina: Ciências Agrárias, Londrina, v. 39, n. 3, p. 1255-1266, maio/jun. 2018 
participação dos custos fixos na composição do custo total e baixas produtividades por animal e por área. Em função disso, a atividade foi altamente dependente da venda de animais para conseguir se custear e apresentar resultados positivos. Dentre os itens componentes do custo operacional efetivo, destacase a alimentação como sendo o de maior representatividade (média de 63,09\%), nas três propriedades estudadas, sendo a participação de impostos considerados fixos $(9,41 \%)$ e despesas diversas $(9,49 \%)$ também expressiva. As propriedades apresentaram elevados custos fixos e pontos de equilíbrio, sendo que em uma das propriedades o mesmo não pode ser determinado, pois o custo variável unitário foi maior que o preço médio do produto no mercado. Na análise econômica, os três sistemas apresentaram margem líquida e resultado positivo, o que indica haver viabilidade de produção no longo prazo.

Palavras-chave: Bovinocultura leiteira. Custo operacional efetivo. Ponto de equilíbrio.

\section{Introduction}

Brazil is a country with predominance of small dairy farms. According to the latest agriculture census, in 2006, of a total of 1.35 million dairy farmers, about 230,000 (17\%) produced between 50 and $200 \mathrm{~L}$ of milk per day and accounted for $39 \%$ of the total production, while $80 \%$ of the total farmers produced less than $50 \mathrm{~L}$ of milk per day. It is also worth highlighting that family farms accounted for $58 \%$ of the total milk produced in 2006 (IBGE, 2011).

In order to keep family farms operational, it is imperative that dairy farms achieve economic viability, since the new generation prefers looking for labor alternatives in cities and have abandoned their farm life (FERRARI et al., 2004). It is noteworthy that work in dairy farms can be extremely exhausting, oppressive, and not very cost-effective, depending on the way the property is managed, which is discouraging for young people belonging to the new generation.

In order to identify whether dairy activity is economically viable, managers must possess the necessary tools to determine production costs; however, doing so involves simple and complex issues, which explains why it has fallen into disuse, according to Santos and Lopes (2014). Information pertaining to obtained revenues and paid expenses are certainly easier to control, but returns, depreciations, and others require more administrative effort. An adequate control and a milk-production cost system that generates information for quick and objective decision-making is fundamental to the success of a property (LOPES et al., 2004a).

In this context, it is crucial that farmers, technicians, dairy plant managers, and others involved in the milk production chain are aware of the production cost components, as well as the factors determining the economic viability or unviability of producing units. This is extremely important, especially in family farms characterized by the low adoption of technology and the low level of education of the owners, but are responsible for most of the country's milk production (IBGE, 2011).

The aim of this study is to estimate the production costs and analyze the cost-effectiveness of three family dairy farms in the municipality of Limeira do Oeste, MG, Brazil, identify the break-even point, the factors that most influence the final costs, and the impacts caused by them.

\section{Material and Methods}

The data used in this study has been obtained from three family dairy farms located in the municipality of Limeira do Oeste, in the region of Pontal do Triângulo Mineiro, Minas Gerais, Brazil, which has a latitude $19^{\circ} 33^{\prime} 05^{\prime \prime} \mathrm{S}$ and a longitude $50^{\circ} 34^{\prime} 50^{\prime \prime} \mathrm{W}$, and is at an altitude of $428 \mathrm{~m}$. The municipality possesses the necessary conditions for dairy activity: competitive costs, aptitude of the rural producers, adequate topography, favorable climatic factors, and a market for product commercialization.

In the three evaluated properties, the herds, composed of crossbred cows (zebus), were raised in an extensive grazing system and received some 
supplementation, without specific technical criteria, and without separating them in homogenous batches. In property 1 , the herd was raised exclusively on pastures and the cows received some supplementation with concentrates. In property 2 , the cows received dietary fiber supplementation with sugarcane (Saccharum officinarum L.) with urea in addition and supplementation with concentrate. In property 3 , feed management included the provision of concentrated feed and soybean meal.

The three properties had a cooling tank, being for collective use in property 2 with other producers also stored milk in the tank. Only property 2 performed artificial insemination and had a milking machine. In properties 1 and 3, cows were bred with bulls and milking was done manually. All the properties carried out only one milking per day.

Data were collected for the period from May 2015 to May 2016, and the survey considered two stages in the gathering of information. In stage one, using forms for characterizing the family farming unit developed by EMATER-MG (Technical Assistance and Rural Extension Company of the State of Minas Gerais) and MDA (Ministry of Agrarian Development) and field notes, a full inventory of the targeted properties was performed to determine the value and useful life of each asset. In the absence of information regarding the value and purchase date, the criterion proposed by Lopes et al. (2004b) was adopted for estimating updated values and the remaining useful life of each inventory item. According to these authors, depending on the state of conservation, the assets can be classified under one of the following categories: great, good, fair, and poor. For assets in good, fair, regular, and poor condition, current values were estimated at $100 \%$, $75 \%, 50 \%$, and $25 \%$, respectively, of the selling price of new assets. For estimating the remaining useful life, the scores of $100 \%, 75 \%, 50 \%$, and $25 \%$ were considered for great, good, fair, and poor states of conservation. The same principle was adopted to evaluate improvements, with the same being measured, evaluated, and classified according to their state of sophistication and conservation. This information was recorded in a descriptive report and depending on the area, the state of conservation, and the finishing standard, a value per $\mathrm{m}^{2}$ of construction was estimated to be multiplied by the improvement area in order to determine its updated value (LOPES et al., 2004b).

In stage two, monthly visits to the properties were made to obtain information regarding production, expenses, and revenues. The collected data were entered into a spreadsheet to conduct a cost-effectiveness analysis of farming systems, which included two production cost structures: the total cost of production, which consists of fixed and variable costs, and operating costs, as proposed by Matsunaga et al. (1976).

To calculate cost-effectiveness, the following formulas were considered: Cost-effectiveness 1 (\%) $=$ Result/(Total fixed assets + Effective operating cost) and Cost-effectiveness $2(\%)=$ Net margin/ (Total fixed assets + Effective operating cost). To calculate profitability, the following formulas were adopted: Profitability $1(\%)=$ Result/Total revenue and Profitability $2(\%)=$ Net margin/Total revenue (LOPES et al., 2011).

The items that comprise the effective operating cost of milk production were divided into the following groups: labor force, food, health, artificial insemination, milking, fixed taxes, energy, and miscellaneous expenses (LOPES; LOPES, 1999).

In the estimation of the return on capital, the savings rate of $6 \%$ per year was applied, and for the return on land, the rent value of the region was adopted, which was $2 \mathrm{~kg}$ of milk ha ${ }^{-1}$ day $^{-1}$ (LOPES et al., 2004a). In order to avoid the duplication of expenses, the analysis did not consider the depreciation of matrices, since the system evaluates the production costs of the activity as a whole, the costs of raising replacement female animals, and the maintenance costs of dry cows (LOPES et al., 2004b). 
The break-even point for the activity was determined by the formula $\mathrm{Q}=\mathrm{FC} /(\mathrm{P}-\mathrm{VCu})$, where $\mathrm{Q}=$ quantity of milk produced during the evaluated period, $\mathrm{FC}=$ total fixed costs in the period, $\mathrm{P}=$ average selling price per liter of milk, and $\mathrm{VCu}=$ unit variable cost (per liter of milk).

The productive and economic indices were compared through descriptive analyses, using MS Excel ${ }^{\circledR}$ software, and grouped into tables for better comparison, discussion, and presentation of results (LOPES et al., 2005).

\section{Results and Discussion}

The summary of resources available in the three properties is presented in Table 1, which shows the equity value of land and the equity value without land, as well as the share rate of each inventory item in relation to this latter value. The high representativeness of the equity value of land in all the properties, mainly in property 3 , which has an area about three times greater than properties 1 and 2 , is observed. The equity value without land was similar in the three properties, which can be verified by the low standard deviation.

Table 1. Resources available in the family farming properties in Limeira do Oeste, MG, Brazil (May 13, 2015 to May 26, 2016).

\begin{tabular}{lccccc}
\hline Specification & Propr. 1 & Propr. 2 & Propr. 3 & SD $^{*}$ & Average \\
\hline Equity value of lands (R\$) & $170,000.00$ & $181,000.00$ & $682,440.00$ & $292,733.62$ & $344,480.00$ \\
Equity value without land (R\$) & $134,500.00$ & $155,050.00$ & $132,850.00$ & $12,368.41$ & $140,800.00$ \\
Value in improvements (\%) & 28.25 & 23.86 & 24.84 & 2.30 & 25.65 \\
Value in equipment (\%) & 1.12 & 3.55 & 4.52 & 1.75 & 3.06 \\
Value in tools (\%) & 0.74 & 0.64 & 0.75 & 0.06 & 0.71 \\
Value in implements (\%) & - & 1.93 & 4.52 & 1.83 & 3.23 \\
Value in machinery (\%) & - & 6.45 & 7.53 & 0.76 & 6.99 \\
Value in vehicles (\%) & 14.87 & 3.22 & 11.29 & 5.97 & 9.79 \\
Value in livestock (\%) & 53.38 & 58.72 & 45.05 & 6.89 & 52.38 \\
Value in furniture (\%) & 1.64 & 1.61 & 1.51 & 0.07 & 1.59 \\
Total fixed assets (R\$) & $304,500.00$ & $336,050.00$ & $815,290.00$ & $286,232.07$ & $485,280.00$ \\
Area (ha) & 17.00 & 18.10 & 56.87 & 22.71 & 30.66 \\
Total number of animals (heads) & 36 & 48 & 35 & 7.23 & 39.67 \\
Equity value of lands ha ${ }^{-1}(\mathrm{R} \$)$ & $10,000.00$ & $10,000.00$ & $12,000.00$ & $1,154.70$ & $10,666.67$ \\
Total fixed assets ha ${ }^{-1}(\mathrm{R} \$)$ & $17,911.76$ & $18,566.30$ & $14,336.03$ & $2,277.04$ & $16,938.03$ \\
\hline
\end{tabular}

$* \mathrm{SD}=$ Standard deviation.

Fixed assets may represent security in terms of assets held by the producer, but paradoxically contribute to an increase in the fixed costs of the properties, which, in small scales of production, can have a significant impact on results. Fixed assets may also have implications for the liquidity of properties, owing to a lack of working capital, since it has limitations when it is transformed into short-term revenues. An example of this is the producer who has equity but often does not have the necessary money to acquire inputs to increase production, at any given time.

Table 2 shows the summary of the costeffectiveness analysis of the properties. The revenue is represented by the monetary value of the returns pertaining to dairy activity, and is obtained 
by multiplying the market price of the milk by the quantity produced. In several agricultural activities, the production process generates several products with revenues representing the value corresponding to the sale of the main product and other products, or even by-products. In this case, only the revenues from the sale of milk and animals (heifers and cows) were considered, since the analyzed properties did not sell manure as a by-product, which was used as organic fertilizer in their grass field. This resulted in a reduction in maintenance expenses, as already mentioned by Lopes et al. (2004a).

Table 2. Summary of the profitability analysis of family agriculture properties in Limeira do Oeste, MG, Brazil (May 13, 2015 to May 26, 2016).

\begin{tabular}{|c|c|c|c|c|c|}
\hline Specification & Propr. 1 & Propr. 2 & Propr. 3 & SD & Average \\
\hline Revenues (R\$) & $48,000.00$ & $78,000.00$ & $57,800.00$ & $15,297.49$ & $61,266.67$ \\
\hline Milk (R\$) & $21,000.00$ & $42,000.00$ & $32,300.00$ & $10,510.15$ & $31,766.67$ \\
\hline Animals (R\$) & $27,000.00$ & $36,000.00$ & $25,500.00$ & $5,678.91$ & $29,500.00$ \\
\hline Total operating cost (TOC) & $27,121.00$ & $33,803.00$ & $25,143.00$ & $4,537.94$ & $28,689.00$ \\
\hline Effective operating cost (EOC) (R\$) & $12,830.00$ & $18,090.00$ & $12,113.00$ & $3,263.59$ & $14,344.33$ \\
\hline Depreciated cost $(\mathrm{R} \$)$ & $5,163.00$ & $6,585.00$ & $3,902.00$ & $1,342.30$ & $5,216.67$ \\
\hline Family labor force (R\$) & $9,128.00$ & $9,128.00$ & $9,128.00$ & 0.00 & $9,128.00$ \\
\hline Total cost $(\mathrm{TC})$ & $43,075.57$ & $52,273.46$ & $53,180.52$ & $5,590.68$ & $49,509.85$ \\
\hline Fixed costs (FC) & $20,051.57$ & $22,637.46$ & $30,716.92$ & $5,563.49$ & $24,468.65$ \\
\hline Return on land (R\$) & $5,318.57$ & $5,549.46$ & $17,643.92$ & $7,050.34$ & $9,503.98$ \\
\hline Return on invested capital (R\$) & $8,070.00$ & $9,303.00$ & $7,971.00$ & 742.10 & $8,448.00$ \\
\hline Fixed taxes $(\mathrm{R} \$)$ & $1,500.00$ & $1,200.00$ & $1,200.00$ & 173.21 & $1,300.00$ \\
\hline Variable costs (VC) & $23,024.00$ & $29,636.00$ & $22,463.60$ & $3,989.07$ & $25,041.20$ \\
\hline EOC without fixed tax $(\mathrm{R} \$)$ & $11,330.00$ & $16,890.00$ & $10,913.00$ & $3,336.97$ & $13,044.33$ \\
\hline Return on working capital (R\$) & $2,566.00$ & $3,618.00$ & $2,422.60$ & 652.72 & $2,868.87$ \\
\hline Gross margin $(\mathrm{R} \$)$ & $35,170.00$ & $59,910.00$ & $45,687.00$ & $12,416.18$ & $46,922.33$ \\
\hline Net margin $(\mathrm{R} \$)$ & $20,789.00$ & $35,069.00$ & $32,657.00$ & $7,592.71$ & $29,535.00$ \\
\hline Result (profit or loss) (R\$) & $4,924.43$ & $25,726.54$ & $4,619.48$ & $12,099.09$ & $11,756.00$ \\
\hline Gross margin/kg of milk (R\$) & 1.44 & 1.20 & 1.20 & 0.14 & 1.28 \\
\hline Net margin/kg of milk $(\mathrm{R} \$)$ & 0.85 & 0.88 & 0.86 & 0.01 & 0.86 \\
\hline Result (profit)/kg of milk (R\$) & 0.20 & 0.51 & 0.12 & 0.21 & 0.28 \\
\hline Profitability $1(\%)$ & 10.26 & 32.98 & 7.99 & 13.82 & 17.08 \\
\hline Cost-effectiveness $1(\%)$ & 1.55 & 7.26 & 0.56 & 3.62 & 3.12 \\
\hline Profitability $2(\%)$ & 43.50 & 56.66 & 56.50 & 7.55 & 52.22 \\
\hline Cost-effectiveness $2(\%)$ & 6.58 & 12.48 & 3.95 & 4.37 & 7.67 \\
\hline Equity variation of the herd (R\$) & $21,650.00$ & $12,400.00$ & $14,200.00$ & $4,904.16$ & $16,083.33$ \\
\hline Amount of traded milk $(\mathrm{kg})$ & 24,500 & 50,000 & 38,000 & 12,757 & 37,500 \\
\hline Amount of consumed milk (kg) & 720 & 720 & 720 & 0 & 720 \\
\hline Total amount of produced milk (kg) & 25,220 & 50,720 & 38,720 & 12,757 & 38,220 \\
\hline Total operating cost/kg of milk (R\$) & 1.11 & 0.68 & 0.66 & 0.25 & 0.82 \\
\hline Effective operating cost/kg milk (R\$) & 0.52 & 0.36 & 0.32 & 0.11 & 0.40 \\
\hline Total cost $/ \mathrm{kg}$ of milk $(\mathrm{R} \$)$ & 1.76 & 1.05 & 1.40 & 0.36 & $\begin{array}{l}1.40 \\
\text { continue }\end{array}$ \\
\hline
\end{tabular}


continuation

\begin{tabular}{llllll} 
Fixed cost $/ \mathrm{kg}$ of milk $(\mathrm{R} \$)$ & 0.82 & 0.45 & 0.81 & 0.10 & 0.76 \\
Variable cost/kg of milk (R\$) & 0.94 & 0.59 & 0.59 & 0.20 & 0.71 \\
Average price/kg of milk (R\$) & 0.86 & 0.84 & 0.85 & 0.01 & 0.85 \\
\hline
\end{tabular}

$\mathrm{SD}=$ Standard deviation; Profitability 1: result/total revenue; Profitability 2: net margin/total revenue; Cost-effectiveness $1:$ result/ (total fixed assets + effective operating cost); Cost-effectiveness 2: net margin/(total fixed assets + effective operating cost); Equity variation of the herd = final value - initial value of the herd.

The values obtained by the sale of milk accounted for $43.75 \%, 53.85 \%$, and $55.88 \%$ of the total revenues of properties 1, 2 and 3, respectively, during the study period, and the values obtained by the sale of animals accounted for $56.25 \%, 46.15 \%$, and $44.12 \%$ of the total revenues of properties 1,2 , and 3 , respectively. In all the evaluated farms, the percentage of revenues from milk sales was well below the average of those in other surveys, while the that related to the sale of animals was well above (FERRAZA et al., 2015; MOURA et al., 2010). This fact was attributed to an atypical situation wherein a large number of animals were marketed by the three farmers motivated by the renovation of the animal herd, through selection and disposal, thus acquiring more productive cows and heifers through the rural credit agency, PRONAF (Program for the Strengthening of Family Farming), after the evaluation period. With regard to stabilized herds, a lower percentage of revenues from the sale of animals would be expected.

The revenues obtained by properties during the evaluation period allowed the return on TOC (total operating cost) and the EOC (effective operating cost), thus configuring a good economic condition of the evaluated properties. The TOC was obtained by adding the EOC (disbursement) to the depreciated cost of assets and the remuneration of the family labor force (Table 2). Depreciation accounted for $19.04 \%, 15.34 \%$, and $15.52 \%$ of the TOC for properties 1,2 , and 3, respectively. These results indicated that property 1 showed the lowest utilization of physical structures compared to properties 2 and 3 , which were quite similar to each other. Although in the literature there is no information about what is a good value for this technical indicator, it can be said that the average asset utilization ratio of the properties was lower than that of family systems in the states of Minas Gerais and Rio de Janeiro, according to Ferrazza et al. (2015). They observed a depreciation of $11.9 \%$ of the TOC, which is well below the values obtained in this study. The same value was considered for the remuneration to the family labor force in all the properties, because family involvement in the daily activities was similar.

The total costs (TC) of the three production systems, which represent the sum of fixed costs (FC) and variable costs (VC), were higher for property 3 , followed by property 2 and property 1 (Table 2 ). This is also justified because the property 3 has an area that is about three times higher than the others (Table 1), and therefore, has the highest fixed costs in relation to return on land.

Fixed costs are independent of the produced quantity and have a long life span, and are good indicators of the productive capacity of the property, whether idle or well sized. They are composed of return on land, return on capital, employer's return, fixed taxes (ITR and IPVA), and depreciation of assets (LOPES et al., 2004a), and account for $46.55 \%, 43.31 \%$, and $57.76 \%$ of the total cost of properties 1, 2, and 3, respectively (Table 2). These results are greater than those found by Ferrazza et al. (2015) in other family systems (27.2\%), indicating that the properties have idle productive capacity and 
extensive fixed assets. No value was attributed to employer's return because all the owners partook in diary activities, and were considered as part of the family labor force. According to Lopes et al. (2006), a high proportion of fixed costs in relation to total cost suggests that the investments are certainly apportioned for milk production that is much higher than the found average, i.e., the available infrastructure is greater than is necessary for the current level of production. In order to reduce the proportion of these costs in relation to the total cost, productivity must be increased to achieve economies of scale, thus making better use of available resources.

Variable costs, which comprise the EOC, except fixed taxes (ITR, IPVA, licensing fee, and compulsory auto insurance), return on working capital, and remuneration of family labor force, accounted for $53.45 \%, 56.69 \%$, and $42.24 \%$ for properties 1, 2 and 3, respectively (Table 2). A greater share of variable costs would be expected in the TC of all properties, which would be indicative of lower fixed assets and higher working capital.

The economic efficiency indicators, namely, gross margin (gross revenue minus EOC) and net margin (gross revenue minus TOC) were satisfactory (positive) across all the properties studied (Table 2). The results of the data suggest that dairy activity in these properties is governed by conditions that would enable them to survive in the short and medium terms with relative stability, and which may even be expanded.

The difference between total revenue and TC, i.e., the result (profit) was positive for all properties. However, it was about five times greater for property 2 , because it produced more milk than the others and had a higher absolute income from the sale of animals. In the analysis of the results (profit) per $\mathrm{kg}$ of milk, property 2 showed profits 2.5 and 4.2 times higher than those of property 1 and property 3 , respectively; property 3 showed the lowest profit per $\mathrm{kg}$ of milk. Considering that the result is determined by subtracting TC from the total revenue of the property, the result per $\mathrm{kg}$ of milk is expressed by this value divided by the amount of milk marketed in the evaluated period. It should be noted that among the evaluated properties, property 1 received the highest price per liter of milk, whereas property 2 earned the lowest.

Since this was an atypical year with high sales of animals, the values received from sales contributed to the positive profitability and cost-effectiveness of the three properties (Table 2). This higher revenue from the sale of animals, at first, may seem favorable. However, a more detailed analysis is necessary, since such a practice can lead to a decrease in productive assets by the sale of animals (LOPES et al., 2005). In the properties under study, such risk was eliminated owing to the subsequent renovation of the herd.

When comparing the three properties with respect to the gross income of the activity per $\mathrm{kg}$ of milk, considering the sale of milk and animals, property 3 showed a lower cost-effectiveness than properties 1 and 2. This can be attributed to a higher percentage of its revenue from milk sales owing to extensive farming and a low rate of voluntary culling. Property 2 had the highest cost-effectiveness, followed by property 1 (Table 2 ).

Analyzing profitability $1(10.26 \%, 32.98 \%$, and $7.99 \%)$ and profitability $2(43.50 \%, 56.96 \%$, and $56.50 \%)$, and cost-effectiveness $1(1.55 \%, 7.26 \%$, and $0.56 \%)$ and cost-effectiveness $2(6.58 \%$, $12.48 \%$, and $3.95 \%$ ), for properties 1,2 , and 3 , respectively, we arrive at the following: there is an attractive value for property 2 , which has a costeffectiveness of 2, well above the return on savings account; however, it is worth pointing out that the sale of animals contributed extensively to this value, although the properties showed a positive variation of biological assets (Table 2).

According to Lopes et al. (2015), in order to make a more realistic analysis of the results, it is necessary 
to verify whether the variation of biological assets was positive by calculating the difference in Reais (R\$), of the value of biological assets at the end and at the beginning of the evaluated period. This variation, when positive, may indicate that the herd is growing, has not yet stabilized, or the price of animals has increased. The variation of biological assets, an index that measures the valuation or the devaluation of a herd, was not similar among the properties (Table 2). In this study, this variation was not proportional to the herd size, i.e., property 2 , which had the largest herd (Table 1), exhibited the lowest asset variation, which is justified by the high sales of animals during the period, thus generating the highest absolute revenue among the evaluated properties. Property 1, despite showing the highest share rate on the sale of animals in total revenues, obtained the highest valuation of biological assets (Table 2).

The average price received per $\mathrm{kg}$ of milk from May 2015 to May 2016 was R\$ $0.85( \pm 0.04)$, which is below the average for the State of Minas Gerais, according to indicators (MILKPOINT, 2016) in the same period.
The EOC represents the average disbursement made by each producer in the analyzed period in order to afford the activity. The items referring to EOC were divided into groups, as presented in Table 3. Food accounted for 65.04\%, 64.05\%, and $60.17 \%$ of the EOC for properties 1,2, and 3, respectively. The percentage for the three properties are above the average (59.65\%) found in other similar studies (BERG; KATSMAN, 1998; LOPES et al., 2004a; CARVALHO et al., 2009). It is expected that food will be the main component of EOC in milk production systems, since production is directly and immediately linked to the feeding of cows. However, the absence of technical criteria for dietary fiber and concentrated supplementation, as observed in the evaluated properties, may also burden the farming system. This happens because less productive animals often receive the same feed as more productive animals, causing zootechnical and economic inefficiency in the use of food, which may help explain the significant share of food in this cost. The disuse of other production inputs in systems with low technological levels of production can also contribute to the prominence of food in the composition of EOC.

Table 3. Representativeness of each group of expenses in the effective operating cost (EOC) of family farming properties in Limeira do Oeste, MG, Brazil (May 13, 2015 to May 26, 2016), in percentage values.

\begin{tabular}{lccccc}
\hline Specification & Propr. 1 & Propr. 2 & Propr. 3 & SD & Average \\
\hline Food & 65.04 & 64.05 & 60.17 & 2.57 & 63.09 \\
Energy & 9.74 & 8.29 & 8.92 & 0.73 & 8.98 \\
Milking & 2.34 & 4.15 & 2.48 & 1.01 & 2.99 \\
Sanity & 3.39 & 5.82 & 6.15 & 1.51 & 5.12 \\
Artificial insemination & - & 2.76 & - & - & - \\
Fixed taxes (ITR, IPVA, licensing and vehicle insurance) & 11.69 & 6.63 & 9.91 & 2.57 & 9.41 \\
Miscellaneous expenses & 7.79 & 8.29 & 12.38 & 2.52 & 9.49 \\
\hline Total & 100.00 & 100.00 & 100.00 & - & - \\
\hline
\end{tabular}

$\mathrm{SD}=$ Standard deviation 
In the energy group, which represented $8.98 \%$, on average, of the EOC (Table 3), electricity and fuel expenses were considered. It is believed that the technological level has affected the effective energy expenditures, but in percentage terms, the three properties maintained very similar average expenditures. Property 2, despite possessing a milking machine, showed a lower proportional expenditure than the others, suggesting that the adoption of milking equipment, properly sized for the property, does not represent significant changes in the cost composition.

The labor force expenses were not reported because all the three properties used family labor and there was no hiring of personnel, thus reducing the EOC. The percentage of expenses with respect to milking was higher in property 2 , as would be expected, since this was the only property with a milking machine.

The average health expenses accounted for $5.12 \%$ of the EOC, which was slightly below the average $(5.91 \%)$ found in other studies (BERG; KATSMAN, 1998; FERRAZZA et al., 2015). A major portion of this was spent on therapeutic products such as antibiotics; another portion was spent on foot-and-mouth disease vaccines; and a small amount was spent on other vaccines considered essential, including antiparasitics.

Regarding the costs of artificial insemination (semen, liquid nitrogen, and other materials), 2.76\% of EOC (Table 3), obtained only for property 2, is slightly below the average (3.03\%) found in other studies (BERG; KATSMAN, 1998).

Fixed taxes, such as the ITR, IPVA, compulsory auto insurance and licensing fee accounted for $11.69 \%, 6.63 \%$, and $9.91 \%$ of EOC for properties
1, 2, and 3, respectively. Lopes et al. (2004a) verified the average percentage of $0.83 \%$ of EOC for these taxes in 16 farms evaluated in the region of the municipality of Lavras, MG, Brazil. Almeida Júnior et al. (2002) obtained the value of $0.75 \%$ for these taxes in the EOC of an intensive system of milk production in the State of São Paulo, Brazil. Ferrazza et al. (2015) considered the effects of taxes on the areas used for milk production, and stated that $0.30 \%$ of these taxes constituted the EOC of family farming systems.

In this study, the observed values can perhaps be explained by a high share of fixed assets in the evaluated properties. Family properties often accumulate underused assets in the form of land, machinery, and vehicles, which can generate economic inefficiency. However, similar to the high proportion of food in the EOC, the absence of other factors that comprise this cost, mainly production inputs, may also help explain the high proportion of these taxes.

Miscellaneous expenses were considered as those that do not fit into the aforementioned groups, such as milk freight; variable taxes; and maintenance expenses for improvements, machinery, and equipment. The average value obtained was $9.49 \%$ of the total EOC.

A low cow:male ratio of $10.0,16.0$, and 14.0 was verified for properties 1,2 , and 3 , respectively (Table 4). This may be explained by the small number of animals in the evaluated properties, which had only 13.33 lactating cows on average. A similar value was obtained by Lopes et al. (2004a) when they studied the cost-effectiveness of 16 milk production units, whereas Ferrazza et al. (2015) obtained a lower average value (6.3) for family farming systems. 
Table 4. Technical and managerial indexes of the studied family farms in the municipality of Limeira do Oeste, MG, Brazil (May 13, 2015 to May 26, 2016).

\begin{tabular}{lccccc}
\hline Specification & Propr. 1 & Propr. 2 & Propr. 3 & SD & Average \\
\hline Number of lactating cows & 10 & 16 & 14 & 3.05 & 13.33 \\
Number of lactating cows/ha & 0.59 & 0.88 & 0.25 & 0.32 & 0.57 \\
Amount of labor force & 1 & 1 & 1 & 0 & 1.0 \\
Animal/labor force ratio & 10 & 16 & 14 & 3.06 & 10.67 \\
Daily milk production (kg of milk) & 69.10 & 138.96 & 106.08 & 34.95 & 104.71 \\
Productivity cow/day (kg of milk) & 6.91 & 8.68 & 7.58 & 0.89 & 7.72 \\
Production of milk/ha/year (kg of milk) & $1,483.53$ & $2,802.21$ & 680.55 & $1,071.22$ & $1,655.43$ \\
Break-even point (kg) & $*$ & $91,545.86$ & $118,665.66$ & $19,176.59$ & $105,105.80$ \\
\hline
\end{tabular}

$\mathrm{SD}=$ Standard Deviation; *not possible to be estimated, since the unit variable cost was higher than the average selling price.

The inefficient feeding of the herd combined with the low genetic aptitude of cows was reflected in the low average daily milk yields found by the lactation matrix that showed an overall average of $7.72 \mathrm{~kg}$ per cow (Table 4).

Regarding the number of lactating cows per hectare available for production, the values found for the stocking rate are well below the potential known for tropical grasses (VILELA et al., 2006). Higher stocking rates would reflect higher productivity per area, which in turn would optimize the use of the land production factor, implying lower representativeness of its return value.

In property 1 , it was not possible to estimate the break-even point, since the unit variable cost was higher than the average-selling price in the market, whereas it could be estimated in properties 2 and 3 . However, the break-even points were not reached (Table 4) mainly owing to the high fixed costs and the small difference between the received price and the variable cost per liter produced. Efforts must be made to reduce the proportion of fixed costs of properties, by increasing production and productivity and/or by reducing fixed assets. The decrease in variable costs per liter of milk would also have a positive impact on this objective.

\section{Conclusions}

Owing to the positive net margins and positive results, the three analyzed farms have sufficient production conditions to remain economically viable in the long-term. The sale of animals is a prevalent factor in the economic viability of the evaluated family systems, considering the current low milk productivity.

The low efficiency in the use of inputs implies idle productive capacity, an increase in the proportion of fixed costs in the composition of the total cost, and low productivity per animal and per given area.

Food was the main component of the effective operating cost in the family farms studied. However, after considering the food, the share of fixed taxes was similar to miscellaneous expenses in terms of representativeness.

The break-even points determined in two of the evaluated properties are far above the current production costs, mainly owing to the high fixed costs and the small difference between the received price and the variable cost per liter produced. 


\section{Acknowledgements}

The authors would like to thank the EMATER - MG (Technical Assistance and Rural Extension Company of the State of Minas Gerais) for making this research possible and the $\mathrm{CNPq}$ (National Council for Scientific and Technological Development) for granting a scholarship to the third author.

\section{References}

ALMEIDA JÚNIOR, G. A.; LOPES, M. A.; PINATTO, F. Efeito da venda de animais na rentabilidade de um sistema intensivo de produção de leite tipo B no estado de São Paulo. In: REUNIÃO ANUAL DA SOCIEDADE BRASILEIRA DE ZOOTECNIA, 39., 2002, Recife. Anais... Recife: [s.n.], 2002. CD-ROM.

BERG, H. V. D.; KATSMAN, T. Custos: comparando despesas na produção do leite. Boletim do Leite, Piracicaba, v. 5, n. 52, p. 3-3, 1998.

CARVALHO, F. M.; RAMOS, O. E.; LOPES, M. A. Análise comparativa dos custos de produção de duas propriedades leiteiras no município de Unaí - MG, no período de 2003 e 2004. Ciência e Agrotecnologia, Lavras, v. 33, p. 1705-1711, 2009. Edição Especial.

FERRARI, D. L.; ABRAMOVAY, R.; SILVESTRO, M. L.; MELLO, M. A.; TESTA, V. M. Dilemas e estratégias dos jovens rurais: ficar ou partir? Estudos Sociedade e Agricultura, Rio de Janeiro, v. 12, n. 2, p. 237-271, 2004.

FERRAZZA, R. A.; LOPES, M. A.; BRUHN, F. R. P.; MORAES, F. Índices de desempenho zootécnico e econômico de sistemas de produção de leite com diferentes tipos de mão de obra. Ciência Animal Brasileira, Goiânia, v. 16, n. 2, p. 193-204, 2015.

INSTITUTO BRASILEIRO DE GEOGRAFIA E ESTATÍSTICA - IBGE. Tabulações especiais do censo agropecuário 2006. Rio de Janeiro: IBGE, 2011. Disponível em: <ftp://ftp.ibge.gov.br/>. Acesso em: 10 jul. 2016.

LOPES, M. A.; LIMA, A. L. R.; CARVALHO, F. M.; REIS, R. P.; SANTOS, I. C.; SARAIVA, F. H. Controle gerencial e estudo da rentabilidade de sistemas de produção de leite na região de Lavras (MG). Ciência e Agrotecnologia, Lavras, v. 28, n. 4, p. 883-892, 2004a.

Efeito da escala de produção nos resultados econômicos de sistemas de produção de leite na região de Lavras (MG): um estudo multicasos. Boletim de
Indústria Animal, Nova Odessa, v. 63, n. 3, p. 177-188, 2006.

Efeito do tipo de sistema de criação nos resultados econômicos de sistemas de produção de leite na região de Lavras (MG). Ciência e Agrotecnologia, Lavras, v. 28, n. 5, p. 1177-1189, 2004b.

. Resultados econômicos de sistemas de produção de leite com diferentes níveis tecnológicos na região de Lavras-MG. Arquivo Brasileiro de Medicina Veterinária e Zootecnia, Belo Horizonte, v. 57, n. 4, p. 485-493, 2005.

LOPES, M. A.; LOPES, D. C. F. Desenvolvimento de um sistema computacional para cálculo do custo de produção do leite. Revista Brasileira de Agroinformática, São Paulo, v. 2, n. 1, p. 1-12, 1999.

LOPES, M. A.; MORAES, F.; CARVALHO, F. M.; PERES, A. C. C.; BRUHN, F. R. P.; REIS, E. M. B. The effect of technological levels on profits of milk production systems participating in the full bucket program: a multicase study. Semina: Ciências Agrárias, Londrina, v. 36, n. 4, p. 2909-2922, 2015.

LOPES, M. A.; SANTOS, G.; RESENDE, M. C.; CARVALHO, F. M.; CARDOSO, M. G. Estudo da rentabilidade de sistemas de produção de leite na região de Nazareno (MG)6cON. Ciência Animal Brasileira, Goiânia, v. 12, n. 1, p. 58-69, 2011.

MATSUNAGA, M.; BEMELMANS, P. F.; TOLEDO, P. E. N.; DULLEY, R. D.; OKAWA, H.; PEDROSO, I. A. Metodologia de custo de produção utilizado pelo IEA. Agricultura em São Paulo, São Paulo, v. 23, n. 1, p. 123139, 1976.

MILKPOINT. Produtor, como está o preço do leite na sua região? Piracicaba: AgriPoint, 2016. Disponível em: $\quad<$ http://www.milkpoint.com.br/cadeia-do-leite/ giro-lacteo/produtor-como-esta-o-preco-do-leite-na-suaregiao-99509n.aspx>. Acesso em: 20 jul. 2016.

MOURA, J. F. P.; PIMENTA FILHO, E. C.; GONZAGA NETO, S.; LEITE, S. V. F.; GUILHERMINO, M. M.; MENEZES, M. P. C. Análise econômica da exploração de leite no Cariri paraibano. Acta Scientiarum Animal Sciences, Maringá, v. 32, n. 2, p. 225-231, 2010.

SANTOS, G.; LOPES, M. A. Indicadores econômicos de sistemas de produção de leite em confinamento total com alto volume de produção diária. Ciência Animal Brasileira, Goiânia, v. 15, n. 3, p. 239-248, 2014.

VILELA, D.; LIMA, J. A.; RESENDE, J. C.; VERNEQUE, R. S. Desempenho de vacas da raça Holandesa em pastagem de coastcross. Revista Brasileira de Zootecnia, Viçosa, MG, v. 35, n. 2, p. 555-561, 2006. 
